\title{
Effects of Light on the Growth and Photosynthesis of Egeria najas Planchon
}

\author{
Washington Luiz Gomes Tavechio and Sidinei Magela Thomaz \\ Universidade Estadual de Maringá; DBI/Nupélia; Av. Colombo, 5790; CEP 87020-900; \\ smthomaz@nupelia.uem.br; Maringá - PR - Brazil
}

\begin{abstract}
Photosynthesis and growth of Egeria najas (Hydrocharitaceae) from a subtropical reservoir (Itaipu Reservoir, Brazil-Paraguay) were measured in response to low light intensities $\left(0-124 \mu M \mathrm{~m}^{-2} \mathrm{~s}^{-1}\right.$ PAR) in the laboratory. Photosynthesis approached saturation in the range of light intensities used and light compensation point was reached at ca. 6-22 $\mu \mathrm{M} \mathrm{m}^{-2} \mathrm{~s}^{-1} P A R$, indicating that this species had a low light requirement for growth. Light stimulated shoot and root relative growth rates $(R G R)$ but it was not related to ratios between root:shoot $R G R$. Laboratory observations indicated that (i) both shoot and root growth were simultaneously stimulated by light and (ii) the low light requirements of E. najas may explain its incidence in the Itaipu Reservoir, where biogenic as well as abiogenic turbidity is high.
\end{abstract}

Key-words: Egeria najas, photosynthesis, growth, light compensation point, rooted macrophytes

\section{INTRODUCTION}

Light is the primary factor limiting submerged aquatic plants (Kirk, 1996), and its effects on photosynthesis and growth of this group have been repeatedly demonstrated in the field (Madsen and Maberly, 1991; Thomaz et al., 1998; Schwarz et al., 2000), as well as in the laboratory (Van et al., 1976; Barko and Smart, 1981; Madsen and SandJensen, 1994). Shade tolerance and light-related morphological changes in some species may confer competitive advantages in light-limiting situations, thereby influencing macrophyte community composition (Barko and Smart, 1981; Tanner et al., 1986). Dominance of submerged macrophytes or an alternative stable turbid state, dominated by phytoplankton in lakes, is also mediated by light, among other factors (Scheffer et al., 1993).
In recent years, several large Brazilian reservoirs have been colonized by submerged native species causing serious damage to water utilization and energy production (Thomaz and Bini, 1998). Despite the quantitative importance of native submerged species in Brazilian reservoirs, most ecological information concerning these plants is found outside of their natural range of occurrence. This affirmation is corroborated by the great amount of information about the ecology and ecophysiology of $E$. densa, for example, which has been generated in ecosystems where it was introduced (e.g., Barko and Smart, 1981; Tanner et al., 1986; Nakanishi et al., 1989; Dutartre et al., 1999).

Lack of basic information is more prominent for potential nuisance species not found in temperate water bodies, though widespread in tropical reservoirs. For example E. najas (Hydrocharitaceae), a South American native

\footnotetext{
* Author for correspondence
} 
species (Cook and Urmi-König, 1984) with great potential for colonizing man-made waterbodies (Thomaz and Bini, 1998) has been little studied. In a recent investigation of several areas of Itaipu Reservoir (Brazil-Paraguay), this species was found in 16 to $54 \%$ of the stands surveyed, with biomass values varying from 98 to $166 \mathrm{gDM} \mathrm{m}^{-2}$ (Thomaz et al., 1999).

In the present work, the effects of light on photosynthesis and shoot and root growth of $E$. najas were investigated in the laboratory. Given that this species is found mainly in turbid waters at Itaipu Reservoir, the main objective was to estimate its light compensation point.

\section{MATERIAL AND METHODS}

Samples of E. najas were collected in the Itaipu Reservoir, a turbid (Secchi $<1.5 \mathrm{~m}$ ) and large $\left(1,350 \mathrm{~km}^{2}\right)$ reservoir located on the BrazilParaguay border $\left(54^{\circ} 30^{\prime} \mathrm{W}, 25^{\circ} 00^{\prime} \mathrm{S}\right)$. The long fetch, together with great depth (mean depth $=$ $22 \mathrm{~m}$ ) and high turbidity of this reservoir limit aquatic macrophytes to sheltered zones of its embayments, which can be characterized as meso to eutrophic (Bini et al., 1999).

Given that the response of growth and photosynthesis to light depends also on temperature and $\mathrm{CO}_{2}$ (Barko and Smart, 1981; Madsen and Sand Jensen, 1994), experiments were carried out under conditions approaching those of the locations where E. najas was collected. This procedure makes measurements of photosynthetic response, as a function of light, ecologically meaningful (Kirk, 1996). Some basic limnological characteristics measured in the water where the plants were collected and from the aquaria where the experiments were carried out are shown in Table 1. Initial experimental conditions had approximately neutral $\mathrm{pH}$, alkalinity values between 352 and $568 \mu \mathrm{M} . \mathrm{L}^{-1}$ and high inorganic carbon and oxygen concentrations.

Table 1 - Ranges of basic limnological variables from samples collected in the field and at the beginning of experiments in the laboratory.

\begin{tabular}{lcc}
\hline & Field & Laboratory \\
\hline $\mathrm{pH}$ & $6.7-7.5$ & $6.5-7.0$ \\
Alkalinity $\left(\mu \mathrm{M} \mathrm{L}^{-1}\right)$ & $444-1,001$ & $352-568$ \\
$\mathrm{CO}_{2}\left(\mu \mathrm{M} \mathrm{L}^{-1}\right)$ & $32-380$ & $91-297$ \\
$\mathrm{HCO}_{3}^{-}\left(\mu \mathrm{M} \mathrm{L}^{-1}\right)$ & $442-998$ & $351-567$ \\
$\mathrm{TIC}\left(\mu \mathrm{M} \mathrm{L}^{-1}\right)$ & $442-823$ & $476-1,348$ \\
Dis. Oxyg. $\left(\mathrm{mg} \mathrm{L}^{-1}\right)$ & $5.1-9.6$ & $6.0-7.9$ \\
\hline
\end{tabular}

Apical shoots (ca. $20 \mathrm{~cm}$ ) of E. najas were sampled from August to October 2000 in stands of three embayments in Itaipu. Water and sediment used in the experiments were collected from the same locations. Material was taken to the laboratory in less than 24 hours and experiments were carried out within 3 days. During this time, plants were kept at $25^{\circ} \mathrm{C}$ in reservoir water at 120 $\mu \mathrm{M} \mathrm{m}^{-2} \mathrm{~s}^{-1}$ (PAR) under 12-hour photo-periods. Use of plants from different stands aimed at obtaining results from varied populations acclimatized to different environmental conditions. Bottles, used in photosynthesis measurements, and aquaria, used in growth experiments, were kept at $25^{\circ} \mathrm{C}$ (approximate spring-fall temperature in Itaipu). Light was provided by 4 OSRAML 15W/10 lamps and light levels were varied with shade fabrics. Given that our main objective was to determine the light compensation point, we prioritized low light levels ( 0 - $\left.124 \mu \mathrm{M} \mathrm{m}^{-2} \mathrm{~s}^{-1} \mathrm{PAR}\right)$.
Rates of photosynthesis were measured in $0.5 \mathrm{~L}$ bottles, containing three 5-cm-long apical shoots. Time of incubation was determined in previous time course experiments in which dissolved oxygen concentrations increased and $\mathrm{CO}_{2}$ concentrations decreased linearly up to 7 hours (data not shown). Based upon this time course, photosynthesis was measured as the difference in concentrations of either $\mathrm{O}_{2}$ or $\mathrm{CO}_{2}$ at zero and five hours of incubation.

Four photosynthesis-light curves with two replicates each (a total of eight incubations) were obtained with shoots from different stands, using results from oxygen concentrations, measured by Winkler titration. On two occasions, curves (with two replicates) were also obtained by measuring total inorganic carbon (measured with a Shimadzu TOC-5000) depletion in the bottles. Shoot dry mass was measured after drying at $105^{\circ} \mathrm{C}$ for 24 hours in an oven. 
The growth-light curves were obtained using shoots from three different stands. 5-cm-long apical portions were planted in $50 \mathrm{ml}$ plastic pots, with sediment collected from inside the stands. The surface layer was covered with washed sand to reduce sediment disturbance during manipulation. Shoots were kept $3-5$ days at $25^{\circ} \mathrm{C}$ in reservoir water, at $120 \mu \mathrm{M} \mathrm{m} \mathrm{m}^{-2} \mathrm{~s}^{-1}$ (PAR) under 12-hour photo-period to stabilize and initiate root formation. Then the planted shoots were kept in aquaria $(10 \mathrm{~cm} \times 10 \mathrm{~cm} \times 35 \mathrm{~cm}$, ca. $3.5 \mathrm{~L})$ for 10 days, under the same light levels defined for lightphotosynthesis experiments. Since the shoots experienced small increases during the 5-7 days of stabilization, their initial dry mass was corrected by adding the estimated mass corresponding to the increase in length. Transformations of fresh into dry mass were done using linear regression relating both variables. Roots were carefully separated from sediment and their length and weight were measured.

Relative growth rate (RGR) of the shoots and roots was calculated as $R G R=\left(\ln W_{t}-\ln W_{0}\right) t^{-1}$, where $W_{0}$ represents the initial and $W_{t}$ the final dry mass and $t$ is the incubation time in days (Sand-Jensen and Madsen, 1991). Curves relating light to photosynthesis and growth were fitted according to the Michaelis-Menten equation, which is considered to be adequate in the absence of photoinhibition (Carr et al., 1997):

$$
P=\text { const }+P_{\max } \frac{\mathrm{PAR}}{\left(K_{m}+\mathrm{PAR}\right)}
$$

where $P$ is the photosynthesis or growth rate, $P_{\max }$ is the maximum photosynthesis or maximum growth rate, $K_{m}$ is the constant corresponding to the light intensity where photosynthesis or the growth rate is one-half the maximum rate and PAR the irradiance. In addition, a constant was introduced in the equation (const), because negative values of photosynthesis and growth were obtained when the light was limiting. Root mass or length were related to light intensities using linear regression.

\section{RESULTS}

Photosynthesis of E. najas apparently approached saturation at light intensities used, both in lightphotosynthesis (Fig. 1) as well as in light growth experiments (Fig. 2).
Light-photosynthesis curves derived from $\mathrm{O}_{2}$ and $\mathrm{CO}_{2}$ measurements were similar $(R=0.68$; $P<0.001 ; N=36$ )(Fig. 1). Small differences were registered for Michaelis-Menten parameters estimated for both methods. When the oxygen method was used, the light compensation point was reached at $22 \mu \mathrm{M} \mathrm{m} \mathrm{m}^{-1}$ PAR, and $K_{m}$ at $32 \mu \mathrm{M} \mathrm{m}^{-2} \mathrm{~s}^{-1} \mathrm{PAR}$. The light compensation point and $K_{m}$ were $13 \mu \mathrm{M} \mathrm{m}^{-2} \mathrm{~s}^{-1}$ and $38 \mu \mathrm{M} \mathrm{m}^{-2} \mathrm{~s}^{-1} \mathrm{PAR}$, respectively, when $\mathrm{CO}_{2}$ was monitored during incubations.

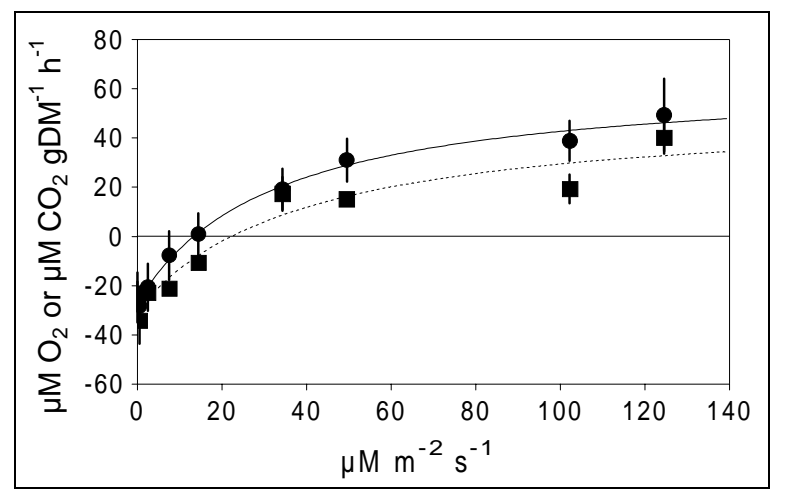

Figure 1 - Photosynthesis rates as a function of light for E. najas. Circles represent dissolved oxygen and quadrats total inorganic carbon. Mean and standard error (4 replicates for oxygen and 2 for carbon) are shown. Curves were fitted using the Michaelis-Menten equation.

The curve growth-light (Fig. 2) paralleled the curve photosynthesis-light $(R=0.96 ; \quad P<0.001$; $N=9)$. Light explained 54\% $\left(R^{2}\right.$ value; $P=0.01$; $N=27$ ) of RGR. Maximum RGR values (about $0.04 \mathrm{~d}^{-1}$ ) were obtained after $50 \mu \mathrm{M} \mathrm{m}^{-2} \mathrm{~s}^{-1}$ PAR, indicating that this is approximately the irradiance required for light saturation. Nevertheless, the light compensation point $\left(6 \mu \mathrm{M} \mathrm{m}^{-2} \mathrm{~s}^{-1} \mathrm{PAR}\right)$ and $K_{m}\left(18 \mu \mathrm{M} \mathrm{m}^{-2} \mathrm{~s}^{-1} \mathrm{PAR}\right)$, estimated by the growth curve were smaller than the values estimated by light-photosynthesis curves. 


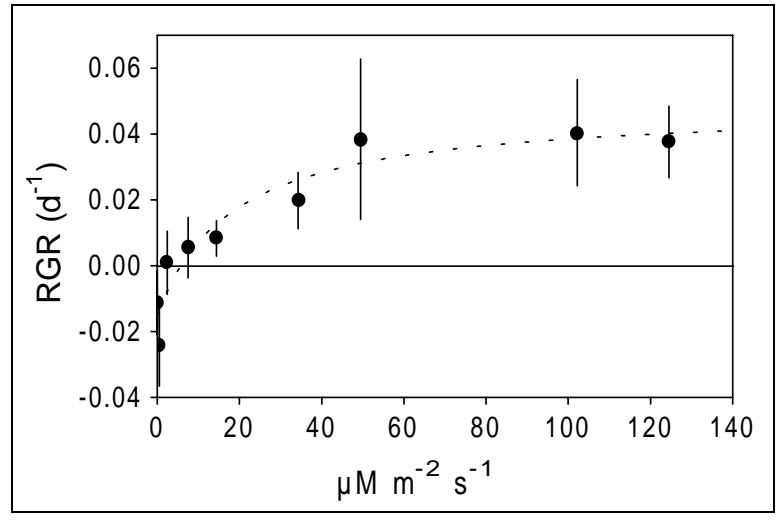

Figure 2 - Light effects upon shoot RGR. Curve was fitted using the Michaelis-Menten equation. Means and standard errors $(N=3)$ are shown.

Effect of light intensities on root RGR was weaker than its effect on shoot RGR, but it was still significant $\left(R^{2}=0.249 ; \quad P=0.008 ; N=27\right)$ (Fig. 3). Root length also increased significantly in response to light $\left(R^{2}=0.325 ; P=0.002 ; N=27\right)$ (Fig. 3 ).

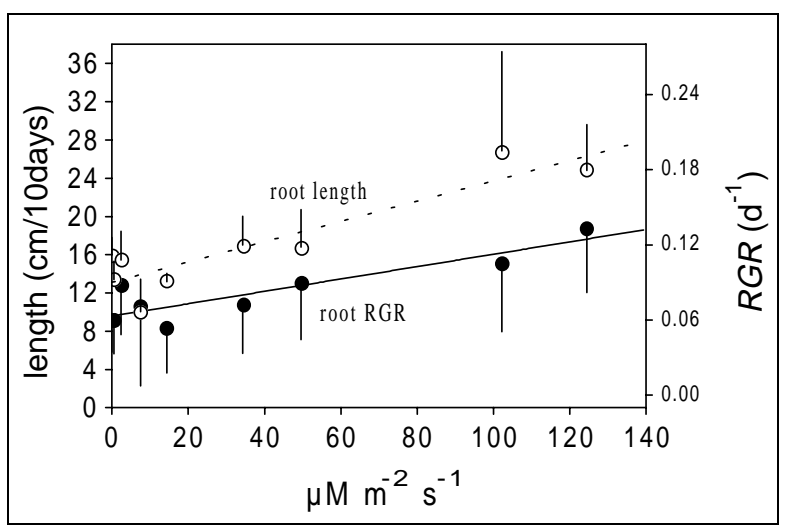

Figure 3 - Light effect upon root length (after growth for 10 days of growth) and root RGR. Linear regressions were used. Means and standard errors $(N=3)$ are shown.

Light intensities did not significantly affect either the ratios of root:shoot $\mathrm{RGR}\left(R^{2}=0.026 ; P=0.422\right.$; $N=27)$ or shoot length $\left(R^{2}=0.141 ; P=0.054 ; N=27\right)$. Despite the lack of relationship between shoot length and light intensities, small shoot increments were observed even under low light intensities (Fig. 4).

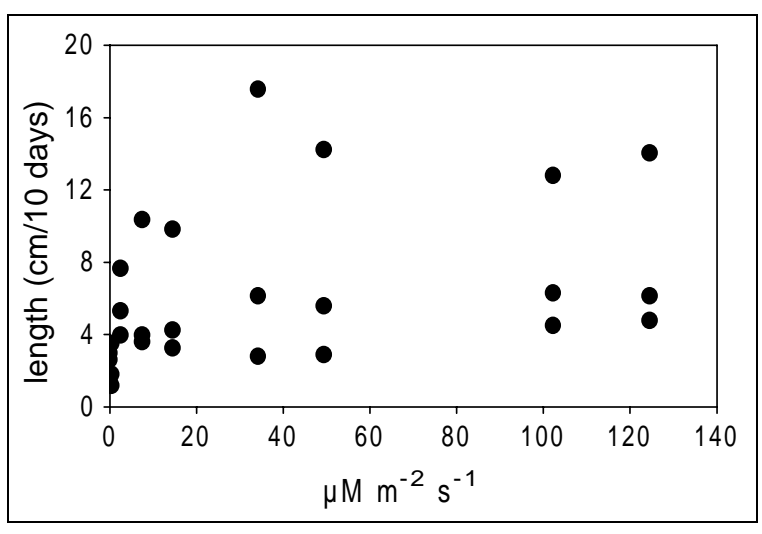

Figure 4 - Light effect upon shoot length (measured after 10 days of growth).

\section{DISCUSSION}

Based on the results of growth and photosynthesis experiments, E. najas collected at Itaipu Reservoir seemed to be well adapted to low light levels for growth, as indicated by the irradiance at light saturation, light compensation points and $K_{m}$. Considering the use of plants from different stands, we believe that the results were representative of the Itaipu Reservoir and not from just one E. najas population. Values for these parameters were low compared with those obtained for several other species of submerged angiosperms under similar temperatures, and were close to results obtained at lower temperatures (Table 2). E. najas develops massive canopies and in view of these low light requirements for growth, this species probably grows predominantly under saturated light levels at Itaipu Reservoir, despite the high turbidity commonly found.

Colonization of depths reached by low light intensities is another important ecological consequence of E. najas low light requirements. In fact, extensive surveys carried out from 1997 to 1999 in three E. najas stands at Itaipu showed that the maximum depth of colonization of this species was, on average, at $1.5 \%$ (confidence interval $95 \%$ $=0.9-2.0$ ) of surface irradiance (Bini and Thomaz, unpublished data). This value is within the lower values found by Schwarz et al. (2000) for submerged rooted plants of similar latitudes (2$4 \%$ ) and much lower than the ones found for submerged angiosperms in temperate lakes $(21.4 \pm 2.4 \%$ SE; Chambers and Kalff, 1985). The relatively constant seasonal maintenance of light, typical in the latitudes of Itaipu, is important for 
colonization of low light intensities depths (SandJensen, 1989). It may have favored E. najas colonization of such depths in this ecosystem. Nevertheless, in addition to low light requirements, there are other possibilities to explain the colonization of depths with low light availability in Itaipu (Thomaz et al., 1998): (i) morphology of $E$. najas, which has a very high proportion of photosynthetic tissues, typical of Hydrocharitaceae, (ii) latitudinal and insolation position of the reservoir, very favourable for light availability and (iii) the canopy-forming architecture of E. najas. According to Barko and Smart (1981), morphological adaptability to low light may be partially responsible for dominance of a given species in eutrophic systems. Thus, it can account for the success of E. najas in the turbid waters of Itaipu.

Independence of shoot length from light intensity was an unexpected result, given that shoot elongation is usually observed under limited light conditions (Barko and Smart, 1981; Kirk, 1996). It suggests that canopies develop independently of light penetration in water, which probably explains canopy occurrences in locations with a various light coefficient attenuation at Itaipu. Additionally, low elongation capacity under shade conditions indicates vulnerability of E. najas to be displaced by other species with such capacity. In this respect, alien species with high elongation capacity (e.g., Hydrilla verticillata, Barko and Smart, 1981) are of special concern, given that this feature enables these species to be competitively superior.

Light also stimulated root formation (as indicated by RGR and elongation). Root development in response to light is supposed to be important in species which depend on sediment as the main source of nutrients, as may be the case of E. najas. Thus, the shoot grows only if the root follows the same tendency. On the other hand, root:shoot RGR ratios were independent of light levels, indicating that energy allocation to shoot and root formation did not differ in response to light intensities. In addition, no translocation of organic compounds to roots under unfavorable conditions was observed; otherwise, a negative relationship between light and root:shoot RGR ratios would have been registered.

Table 2 - Comparisons of the irradiance required for light saturation (L.S.), half saturation constant $\left(K_{m}\right)$, and light at the compensation point (L.C.P.) for several species of freshwater submerged macrophytes (values in $\mu \mathrm{M} \mathrm{m} \mathrm{m}^{-2} \mathrm{~s}^{-1}$ PAR). Temperatures are given in ${ }^{\circ} \mathrm{C}$. Methods were: Li-Phot.: light-photosynthesis curves carried out with apical portions and measured as the alterations of either $\mathrm{O}_{2}$ or $\mathrm{CO}_{2}$ in the water; Gr-Exp.: light-growth curves, obtained in experiments where shoots were planted and the growth rates measured. Values 1 - Barko and Smart (1981); 2 - Van et al. (1976); 3 - Titus and Adams (1979); 4 - Madsen and Sand-Jensen (1994); 5 - Salvucci and Bowes (1982); 6 Sand-Jensen and Madsen (1991).

\begin{tabular}{lccccc}
\hline Species/author & Temperature & Method & L.S. & $\boldsymbol{K}_{\boldsymbol{m}}$ & L.C.P. \\
\hline Egeria densa $(1)$ & 24 & Li-Phot & $>1.050$ & - & - \\
Hydrilla verticillata (1) & 24 & Li-Phot & 1.050 & - & - \\
Hydrilla verticillata (2) & 30 & Li-Phot & 600 & 80 & 15 \\
Ceratophyllum demersum (2) & 30 & Li-Phot & 700 & 145 & 35 \\
Myriophyllum spicatum (2) & 30 & Li-Phot & 600 & 120 & 35 \\
Cabomba caroliniana (2) & 30 & Li-Phot & 700 & 160 & 55 \\
Vallisneria americana (3) & 25 & Li-Phot & 140 & $60-197$ & - \\
Myriophyllum spicatum (3) & 25 & Li-Phot & $>2.000$ & $164-365$ & - \\
Elodea canadensis $(4)$ & 8 & Gr-exp* & $\sim 105$ & - & $3.1-4.4$ \\
Callitriche caphocarpa (4) & 8 & Gr-exp* & 60 & - & $5.1-17.8$ \\
Myriophyllum brasiliense (5) & 30 & Li-Phot & $250-300$ & - & $42-45$ \\
Ceratophyllum demersum (6) & 7 & Gr-exp* & - & - & 7.2 \\
Elodea canadensis $(6)$ & 7 & Gr-exp* & - & - & $5.0-10.0$ \\
Ranunculus peltatus $(6)$ & 7 & Gr-exp* & - & - & $13-22$ \\
Egeria najas (this study) & 25 & Li-Phot & - & $32-38$ & 6 \\
Egeria najas (this study) & 25 & Gr-exp** & $\sim 60$ & 18 & 6 \\
\hline I6h & & & & &
\end{tabular}

*16h light/8h dark cycle; ** 12h light/12h dark cycle. 
In summary, our results provided a first insight into the basic ecophysiological features of E. najas and indicated that low light requirements might be a possible explanation for its success in the turbid waters of the Itaipu Reservoir. Further investigations concerning the interactions of light and nutrients or $\mathrm{CO}_{2}$, as well as experiments with other submerged species, are being carried out to elucidate why $E$. najas co-occur with other native submerged macrophytes in several reservoirs of the La Plata basin.

\section{ACKNOWLEDGEMENTS}

We are grateful to Dr. Kevin Joseph Murphy (Glasgow University) and Dr. Luis Maurício Bini (University of Goiânia) for constructive criticism, MSc. Sandra Pierini for manuscript review and to John Stanley for English corrections. The technician Raul Ribeiro was helpful in field samplings. Funds were provided by Itaipu Binacional. CNPq provided a scholarship to $\mathrm{W}$. G. Tavechio (PIBIC Program). S. M. Thomaz belongs to the Research Productivity Program CNPq.

\section{RESUMO}

A resposta da fotossíntese e crescimento de Egeria najas (Hydrocharitaceae) a baixas intensidades de radiação luminosa $\left(0-124 \mu \mathrm{M} \mathrm{m}^{-2} \mathrm{~s}^{-1}\right.$ RFA) foi medida em exemplares coletados no reservatório de Itaipu. A fotossíntese aproximou-se da saturação nas intensidades de radiação utilizadas e o ponto de compensação foi atingido a aproximadamente 6-22 $\mu \mathrm{M} \mathrm{m}^{-1} \mathrm{RFA}$, indicando que esta espécie apresenta um baixo requerimento de radiação subaquática para crescimento. A radiação subaquática estimulou as taxas de crescimento relativas das porções fotossintéticas (caules e folhas) e das raízes, mas não houve relação entre a radiação e a razão entre as taxas de crescimento relativo das partes fotossintéticas e raízes. Observações de laboratório indicaram que: i. tanto as raízes como as porções fotossinteticamente ativas foram estimuladas pela radiação subaquática e ii. o baixo requerimento por radiação de E. najas pode explicar a incidência desta espécie no reservatório de Itaipu, onde a turbidez biogênica e abiogênica é elevada.

\section{REFERENCES}

Barko, J. W. and Smart, R. M. (1981), Comparative influences of light and temperature on the growth and metabolism of selected submersed freshwater macrophytes. Ecolog. Monogr., 51 : (2), 219-235.

Bini, L. M.; Thomaz, S. M.; Murphy, K. J. and Camargo, A. F. M. (1999), Aquatic macrophyte distribution in relation to water and sediment conditions in the Itaipu Reservoir, Brazil. Hydrobiologia, 415, 147-154.

Carr, G. M., Duthie, H. C. and Taylor, W. D. (1997), Models of plant productivity: a review of the factors that influence growth. Aquat. Bot., 59, 195-215.

Chambers, P. A. and Kalff, J. (1985), Depth distribution of biomass of submerged aquatic macrophytes communities in relation to Secchi depth. Can. J. Fish. Aquat. Sci., 42, 701-709.

Cook, C. K. K. and Urmi-König, K. (1984), A revision of the genus Egeria (Hydrocharitaceae). Aquat. Bot., 19, 73-96.

Dutartre, A., Haury, J., Jigorel, A. (1999), Succession of Egeria densa in a drinking water reservoir in Morbihan (France). Hydrobiologia, 415, 243-247.

Kirk, J. T. O. (1996), Light and photosynthesis in aquatic ecosystems. $2^{\text {nd }}$ ed. Cambridge University Press, New York.

Madsen, T. V. and Maberly, S. C. (1991), Diurnal variation in light and carbon limitation of photosynthesis by two species of submerged freshwater macrophyte with a differential ability to use bicarbonate. Freshwater Biol., 26, 175-187.

Madsen, T. V. and Sand-Jensen, K. (1994), The interactive effects of light and inorganic carbon on aquatic plant growth. Plan Cell Environ., 17, 955-962.

Nakanishi, M., Saraceni, C. and Kurata, A. (1989), Comparison of some limnological variables in the waters between the upper and lower littoral areas within an Egeria stand. Arch. Hydrobiol., 116 : (3), 313-331.

Salvucci, M. E. and Bowes, G. (1982), Photosynthetic and photorespiratory responses of the aerial and submerged leaves of Myrioplyllum brasiliense. Aquat. Bot., 13, 147-164.

Sand-Jensen, K. (1989), Environmental variables and their effect on photosynthesis of aquatic plant communities. Aquat. Bot., 34, 5-25.

Sand-Jensen, K and Madsen, T.V. (1991), Minimum light requirements of submerged freshwater macrophytes in laboratory growth experiments. J. Ecol., 79, 749-764.

Schwarz, A-M., Howard-Williams, C. and Clayton, J. (2000), Analysis of relationships between maximum depth limits of aquatic plants and underwater light in 63 New Zealand lakes. New Zeal. J. Mar. Fresh., 34, 157-174. 
Scheffer, M, Hosper, S. H., Meijer, H. L., Moss, B. and Jeppesen, E. (1993), Alternative equilibria in shallow lakes. TREE, 8 : (8), 275-279.

Tanner, C. C., Clayton, J. S. and Harper, L. M. (1986), Observations on aquatic macrophytes in 26 northern New Zealand lakes. New Zeal. J. Bot., 24 : (4), 539-551.

Thomaz, S. M., Bini, L. M. and Souza, D. C. (1998), Biomass and maximum colonization depth of Egeria najas Planchon (Hydrocharitaceae) at Itaipu Reservoir, Brazil. In: Monteiro, A.; Vasconcelos, T. and Catarino, L. (eds.). Management and Ecology of Aquatic Plants (Proc. 10 ${ }^{\text {th }}$ EWRS Symposium on Aquatic Weed). Lisbon : EWRS/APRH. pp. 223-226.

Thomaz, S. M. and Bini, L. M. (1998), Ecologia e manejo de macrófitas em reservatórios. Acta Limnologica Brasiliensia, 10 : (1), 103-116.

Thomaz, S. M.; Bini, L. M.; Souza, M. C.; Kita, K. K. and Camargo, A. F. M. (1999), Aquatic macrophytes of Itaipu reservoir, Brazil: Survey of species and ecological considerations. Braz. Arch. Biol. Techn., 42 : (1), 15-22.

Titus, J. E. and Adams, M. S. (1979), Coexistence and the comparative light relations of the submerged macrophytes Miriophyllum spicatum L. and Vallisneria americana Michx. Oecologia, 40, 273-276.

Van, T. K.; Haller, W. T. and Bowes, G. (1976), Comparison of the photosynthetic characteristics of three submersed aquatic plants. Plant Physiol., 58, 761-768.

Received: April 26, 2001; Revised: October 22, 2001; Accepted: March 04, 2002. 